\title{
Gagasan Pengembangan Metode Konseling Islami dalam Perspektif Integratif
}

\author{
Hajir Tajiri \\ UIN Sunan Gunung Djati Bandung \\ E-mail: manghajir@gmail.com
}

\begin{abstract}
Methodologically, the development of Islamic social sciences including Islamic counseling is not adhered to the closed system. The development of social sciences of Islam despite its underlying principles have proliferated since the heyday of Islam, but after it stagnated until a long time, and then science appeared and evolved spectacularly in the Western world. The position of Islamic science must show his position on the development of Western science, selecting and sorting, adapting back and perform filtering on a region where science is consistent or inconsistent with the principles of Islam. Some scientific theories developed in the West recognized store a number of shortcomings, but as a product of science the theory is not entirely rejected, and even quite useful in explaining the phenomenon of human behavior. Islamic counseling with integrative approach is allowing for the development of new methods of Islamic counseling.
\end{abstract}

\section{Kata Kunci:}

Konseling Islami, Gagasan Pengembangan, Perspektif Integratif

\section{A. Pendahuluan}

Psikologi telah memperkenalkan sejumlah teori besar tentang perilaku manusia. Dengan ilmu ini konselor mengenal bagaimana perilaku manusia terbentuk. Ilmu tersebut juga membantu para konselor dalam memahami sebab-sebab munculnya masalah perilaku serta model pemecahannya. Sejumlah teori telah dilahirkan antara lain psikodiagnostik, behaviorisme, humanisme, kognitivisme hingga spiritualisme. 
Sejumlah pemikir mutakhir mulai melakukan kajian terhadap teori-teori itu, umumnya mereka memandang bahwa sebagai hasil kerja ilmiah teori itu sangat berarti bagi perkembangan psikologi. Namun demikian layaknya ilmu yang sifat kebenarannya relatif dan tentatif selalu saja ada celah yang dinilai kurang. Kajian kritispun banyak dilakukan termasuk dari kalangan pemikir muslim. Dalam beberapa hal teori itu mengandung kelemahan.

Kehadiran perspektif Islam memberikan angin baru gagasan pengembangan bimbingan dan konseling. Islam mengakui atau memandang sejalan beberapa premis yang diperkenalkan teori psikologi Barat. Islam sebagai alat analisis, bukan hanya mampu menjelaskan gejala kebaikan, tetapi juga mengenal lawan dari kebaikan. Libido sexuality, sering dianggap pendapat Freud yang terlalu menyeder hanakan manusia. Faktanya memang sesuai dan Islam mengakui adanya naluri atau insting seks pada manusia (lihat QS. Al-Imran ayat 19). Hanya saja Islam tidak berhenti sampai disitu, selain mengakui adanya dorongan seks, Islam juga memperkenalkan bagaimana pemenuhan dorongan seks itu dengan cara yang terhormat dan beradab.

Freud memperkenalkan teori mimpi dan penafsirannya sebagai alat untuk membaca permasalahan konseli. Islam dalam beberapa sumber, Nabi Yusuf ada disebut mampu menafsirkan bagaimana mimpi itu benar-benar mengilhami bagaimana manusia seharusnya berperilaku. Dikalangan Filosof Muslim Ibnu Sirrin telah terbukti berhasil menyusun buku mengungkap tabir mimpi.

Pandangan behaviorisme memperkenalkan adanya pengaruh kuat lingkungan dalam membentuk kepribadian seseorang. Bahwa setiap manusia terlahir bagaikan kertas putih atau tabula rasa, mau jadi apa mereka, mau seperti apa kepribadian mereka sangat dipengaruhi oleh warna yang dituliskan terhadap kertas putih itu. Kendati kekurangan teori ini tidak bisa dipungkiri seperti pernyataan yang menyebutkan bahwa pandangan tersebut telah menyebabkan cara pandang terhadap manusia yang terlalu simplistik karena menapikan adanya bakat bawaan atau potensi yang dapat tumbuh dan berkembang pada seseorang. Namun demikian sebagai teori tidak sepenuhnya ditolak dan diakui oleh para ilmuan kontemporer sebagai salah satu alat analisis yang dapat diterima.

Dalam perspektif Islam lagi-lagi tidak dapat sepenuhnya menolak behaviorisme, sebab sebagaimana sabda Nabi Saw., "Setiap bayi terlahir 
dalam keadaan fitrah, kedua orang tuanyalah yang menjadikan ia Yahudi, Nasroni maupun Majusi", menunjukkan adanya pengakuan terhadap cara pandang behavioris itu, hanya saja Islam selain mengakui adanya pengaruh kuat lingkungan, potensi bawaan juga tidak dapat diabaikan. Istilah yang diperkenalkan Islam dengan kata "fitrah" sangat berbeda dengan istilah kertas putih, dalam fitrah menggambarkan adanya potensi kebaikan sedangkan kertas putih menggambarkan kosong sama sekali.

Itulah sebabnya dalam perkembangan psikologi muncul humanisme yang sangat menghargai potensi bawaan pada manusia, mengakui adanya potensi kognitif dan emotif pada manusia, adanya kecerdasan, kasih sayang, harga diri dan lain-lain. Hanya saja jika dilihat dari sudut Islam humanisme yang berkembang di Barat itu masih menyimpan kekurangan karena meniadakan peran tuhan atau potensi dasar ketuhanan pada manusia.

Pemikiran di atas menggambarkan adanya tahapan dalam perkembangan teori psikologi menuju ke arah kesempurnaan. Perkembangan itu menuju titik temu dengan teori psikologi Islam. Psikologi Islam sejak awal telah memperkenalkan cara pandang yang utuh tentang manusia. Pengetahuan Islam pernah berkembang sangat pesat hingga mengalami kemandegan, sementara psikologi Barat merangkak dan semakin dinamis berkembang dengan sain modernnya. Maka Perkembangan sistem pengetahuan Islam tidak dapat mengabaikan arti penting perkembangan sain yang pernah berkembang di Barat itu. Tulisan ini memandang penting salah satu pendekatan bimbingan konseling yaitu pendekatan integratif. Pendekatan ini memberikan ruang bagi memadunya beberapa pandangan tentang pendekatan psikologi antara Islam dan Barat. Bagaimanakah wujud integrasi psikologi antara Islam dan Barat dalam pengembangan metode konseling Islami?

\section{B. Perspektif Integraif}

Perspektif integrasi adalah sebuah perspektif dalam madzhab bimbingan konseling yang berasumsi bahwa tidak ada teori tunggal yang diakui cukup komprehensif untuk memperhitungkan kompleksitas perilaku manusia khususnya ketika tipe-tipe klien dan masalah spesifiknya dipertimbangkan. Karena tidak ada teori yang memiliki sebuah kebenaran yang paten, dan karena tidak ada perangkat tunggal 
dari teknik konseling yang dianggap efektif dalam bekerja dengan beragam populasi klien, menyebrang batas-batas dengan mengembangkan integratif dalam praktek konseling (Kelly and Lazarus in Gerald Corey, 2005: 464).

Para praktisi yang terbuka terhadap perspektif integrasi menemukan bahwa beberapa teori memainkan peranan krusial dalam pendekatan konseling. Setiap teori memiliki kontribusi yang unik dalam ranah keahliannya. Dengan menerima masing-masing teori yang tak terelakan memiliki kelebihan dan kekurangan, para praktisi mendapatkan beberapa basis untuk mulai mengembangkan sebuah teori yang menguatkan mereka. Pengembangan perspektif integratif adalah usaha sepanjang hayat yang ditempuh melalui pengalaman (Corey, 2005: 464).

Sejak awal tahun 1980an, psikoterapi telah ditandai oleh pergerakan cepat menuju integrasi. Pergerakan ini didasarkan pada gabungan orientasi terbaik yang berbeda sehingga model-model teoretik lebih sempurna dapat diartikulasikan dan tritmen yang lebih efisien dikembangkan (Goldfried \& Castonguay dalam Corey, 2005: 464)

Pendektan konseling integrative merupakan pertanda terbaik yang berusaha melihat kesamping dan melintasi satu pendekatan untuk melihat apakah dapat dipelajari dari perspektif lain. Pendekatan integratif ditandai oleh keterbukaan terhadap beragam cara mengintegrasi kan teori-teori dan teknik-teknik yang berbeda. Ada tiga cara yang paling umum untuk tujuan ini yaitu teknik elektisme, integrasi teori, dan pendekatan faktor umum. Teknik elektisme cenderung fokus pada perbedaan, memilih dari beragam pendekatan, dan kumpulan teknik-teknik. Cara ini untuk menggunakan beberapa teknik dari aliran yang berbeda tanpa perlu terikat pada posisi teoretik yang telah melahirkannya.

Sebaliknya integrasi teori mengacu kepada penciptaan konseptual atau teoretik diluar campuran teknik-teknik. Cara ini bertujuan menghasilkan kerangka kerja konseptual yang menggabungkan dua atau lebih pendekatan teoretik di bawah asumsi sehingga hasilnya lebih kaya dari teorinya sendiri. Sedangkan pendekatan faktor-faktor umum mencari elemen-elemen umum melintasi sistem teoretik yang berbeda. Meskipun beberapa perbedaan di antara teori-teori, sebuah inti pengakuan dari praktik konseling yang terdiri dari variabel-variabel non-spesifik bagi semua terapis. Faktor-faktor umum ini 
dipertimbangkan sekurang-kurangnya sebagai penting dalam memperhitungkan hasil terapetik sebagai faktor unik yang membedakan satu teori dari yang lain.

Dalam perspektif integratif, BKI bukan hanya dilihat sebagai tritmen melainkan juga dari segi proses penggalian, pengumpulan dan penafsiran atas kompleksitas masalah yang dijumpainya. Problem manusia tidak semata-mata dilihat dari segi rendahnya keimanan tetapi juga akan dilihat apa faktor-faktor yang menyebabkan rendahnya keimanan. Keimanan bukan hanya ditempatkan sebagai cita ideal yang harus dimiliki seseorang, akan tetapi bagaimana cita ideal itu dapat terbentuk. Ada dimensi lain yang turut berpengaruh terhadap kondisi keimanan seseorang.

Demikian juga dengan tritmen. Penggunaan tritmen tidak sematamata hanya menggunakan teknik BKI, seperti muhasabah, dzikrullah atau do'a. Tetapi teknik yang bersifat rasional yang lain termasuk yang pernah berkembang di Barat, sepanjang memiliki relevansi dapat dipergunakan. BKI bukan hanya menyadarkan orang agar mau berdzikir atau berdo'a, BKI juga harus mampu memperbaiki cara berpikir seseorang (klien), mengganti pikiran lama dengan pikiran yang baru. Teknik konseling yang menekankan perubahan pola pikir (changing mindset), menguji atau testing pikiran dan harapan-harapannya, relevan dan dibutuhkan oleh BKI.

\section{Beberapa Gagasan Pengembangan Metode Konseling}

\section{Pendekatan Kognitif Islami}

Pendekatan ini merupakan ikhtiar memadukan pendekatan kognitif dalam pendekatan Islam. Usaha ini dapat memastikan bahwa pendekatan kognitif bukan hanya milik Barat, tetapi juga telah diterapkan di dunia Islam. Dalam term Islam dikenal dengan dakwah yaitu sebagai upaya mengubah cara pikir masyarakat dari jahiliyah kepada Islam. Sejarah pun telah menunjukkan bagaimana pendekatan itu diterapkan baik secara individual maupun secara kelompok. Ketertinggalannya terletak pada pendalaman hakikat kognitif-nya.

Dalam pikiran Barat, kognitif atau kognisi adalah pikiran-pikiran termasuk di dalamnya kepercayaan-kepercayaan, asumsi-asumsi, harapan-harapan, atribusi dan sikap-sikap (Spiegler \& Guevremont, $2003: 302$ ). 
Kognisi artinya kualitas dan kuantitas pengetahuan yang dimiliki (Rakhmat, 1989:80). Kualitas diri seseorang ditentukan oleh kualitas pikirannya. Kognisi merupakan bagian intelek yang merujuk pada penerimaan, penafsiran, pemikiran, pengingatan, penghayalan atau penciptaan, pengambilan keputusan dan penalaran (Surya, 2009: 76).

Kognisi dalam konteks bimbingan dan konseling lebih tertuju pada asumsi tentang masalah perilaku dan teknik-teknik atau metode sebagai langkah pemecahan dan penangannya. Teknik-teknik tersebut antara lain teknik restrukturisasi kognitif, modifikasi kognitif, teknik mengubah pikiran lama dengan pikiran baru, menguji gagasan sendiri, dan lain-lain. Teknik-teknik tersebut berkembang karena asumsi bahwa masalah perilaku muncul karena pikiran yang salah (error think), atau kebiasaan perilaku buruk terlahir karena pikiran-pikiran yang sering muncul dan diterima sebagai kebenaran (authomatic thoughts).

Dalam perspektif kognitif, problema utama kehidupan yang dialami konseli bersumber pada asumsi-asumsi yang salah yang membentuk sikap, keyakinan maupun harapan-harapan. Kognisi sebagai bagian intelek yang merujuk pada penerimaan, penafsiran, pemikiran, pengingatan, penghayalan atau penciptaan, pengambilan keputusan dan penalaran merupakan faktor penting dan berpengaruh terhadap perilaku (John Mc Leod,2008:151; Surya,2003:76).

Peluang integrasi pendekatan kognitif dengan Islam dapat didasarkan pada fakta agama lain yang juga menerapkan pendekatan kognitif dalam kegiatan misi mereka. Menurut Aisha Hamdan (2008) pada beberapa tahun terakhir, usaha-usaha dibuat untuk menintegrasikan agama berbasis konsep dan kepercayaan dalam konteks pendekatan kognitif-perilaku. Ini melibatkan penggantian kepercayaan yang merusak dan atribusi dari diri, orang lain dan dunia dengan keberagamaan yang lebih positif berbasis kepercayaan dan atribusi. Penelitian mendemonstrasikan efektivitas penggunaan beragam pendekatan ini terhadap beberapa penduduk yang berbeda

Propst (Hamdan, 2008) telah membandingkan terapi kognitifperilaku agama dan non agama. Dalam terapi kelompok agama, terapis menyediakan rasional agama Kristen untuk prosedur, menggunakan argumen agama untuk menkoter pikiran-pikiran irasional, dan menggunakan prosedur imag agama. Penggunaan model terapi rasional emotif , Johnson dan Ridley (1992) mengarahkan partisipan untuk menentang pikiran-pikiran irasional menggunakan bible. 
Seperti itu pula pendekatan Islam dengan kognitif-perilaku. Fakta keberhasilan dakwah Rasul masa lalu menunjukkan betapa rasul sangat mengandalkan kehebatan kemampuan berlogika secara benar. Misal ketika ada orang Qureisy yang ragu terhadap hari kebangkitan. Mereka berkata: "Wahai Muhammad! Apakah jika kami mati kemudian menjadi tanah dan tulang . Apakah kami akan dibangkitkan kembali? ", "Siapa yang akan menghidupkan tulang belulang yang telah hancur begini?". Rasul menjawab:" Yang akan membangkitkan kembali semua itu adalah Dzat yang telah menciptakannya pertama kali". Apa susahnya bagi Allah menghidupkan kembali yang sudah mati padahal sebelumnya Allah telah menciptakan semua yang asalnya tiada menjadi ada, dan apatah lagi dari yang sudah atau pernah ada. Ini hanyalah salah satu perumppamaan yang diberikan, dan betapa banyak Rasul menggunakan pendekatan kognitifnya sehingga orang-orang Qureisy akhiurnya masuk Islam.

\section{Pendekatan Behavioris Islami}

Pendekatan ini merupakan upaya memadukan pandangan behavioris dengan Islam khususnya yang berkait dengan perilaku manusia. Behaviorisme berpandangan bahwa pembentukan perilaku, watak maupun kepribadian sangat ditentukan oleh pengaruh kuat faktor lingkungan. Boleh jadi faktor lingkungan tersebut termasuk di dalamnya letak geografis, kondisi cuaca, kebiasaan keluarga, pengaruh teman dan bahkan perkembangan teknologi.

Pemahaman behavioris tersebut sebagaimana telah ditancapkan oleh perintisnya J.B. Watson dan lain-lain yang menekankan pengaruh ekstrim lingkungan sehingga manusia ibarat kertas kosong yang diukir oleh lingkungan. Manusia ibarat robot yang geraknya ditentukan oleh pengenalan faktor lingkungan. Pengenalan masalah pada seseorang pun selalu dihubungkan dengan faktor lingkungan seperti apa yang pernah dia alami selama ini, kesalahan belajar yang bagaimana yang membuat tindakannya menjadi menyimpang, dan lain-lain.

Pendekatan konseling yang ditawarkan berdasarkan asumsi di atas, maka anak manusia jika perilaku dan kepribadiannya ingin baik maka ia harus diperkenalkan dengan lingkungan yang baik. Apa saja yang merupakan lingkup pengalaman manusia baik itu yang bersumber dari penglihatan, pendengaran, pembiasaan harus merupakan bentuk pengaruh lingkungan yang baik. 
Seperti halnya juga dalam merehabilitasi perilaku yang rusak, maka sedapat mungkin klien diperkenalkan dengan perilaku baru yang memang berbeda dengan kebiasaannya, intensitas pengenalan kebiasaan akan menentukan perilaku mana pada akhirnya harus ia pilih. Hanya saja pendekatan yang murni behavioris ini sepertinya tidak mudah atau kurang efektif. Disinilah letak kelemahannya. Oleh karena itu pendekatan ini lebih tepat jika digunakan hanya untuk membaca atau mengidentifikasi masalah perilaku pada seseorang.

Pendekatan behavioris akan menjadi efektif jika pendekatan ini dikawinkan dengan dimensi perilaku yang tidak tampak (covert behavior) seperti pikiran, harapan-harapan, kecenderungankecenderungan, dan lain-lain seperti dianut madzhab behavioris kontemporer.

Beberapa terapis behavior kontemporer mulai dapat mengenal dan mengakui adanya peristiwa-peristiwa internal dalam perilaku. Sesuatu yang ada dalam diri seseorang (within person) menjadi amat penting - misalnya intentions, pikiran-pikiran (thoughts), harapanharapan (expectations), rencana (plans), commitments, ancaman (threats)-dapat menjadi amat penting, meskipun peristiwa-peristiwa internal ini dibentuk dan dipengaruhi oleh ganjaran-ganjaran (rewards) dan hukuman-hukuman (funishments) dari lingkungan. Berdasarkan pandangan ini, manusia dapat dilatih atau ditolong untuk mengembangkan umanis diri terhadap impuls-impuls, pola-pola reaksi, dan perilaku sosialnya; dilakukan dengan menggunakan faktor-faktor baik internal maupun eksternal (Lazarus, 1976: 339).

Integrasi dengan Islam, atau pendekatan umanisticc Islami mensyaratkan pelaziman perilaku itu didasarkan atau mengacu kepada nilai-nilai karakter Islami, pola uman maupun tindakan. Dalam Islam dikenal konsep penanaman nilai itu berlaku sejak manusia dilahirkan ke dunia, dengan pengenalan situasi yang positif, seperti lapadz kalimah thayyibah, kebiasaan berpikir, tata perilaku, tata keyakinan, dan lainlain. Bahkan bagaimana mengarahkan jenis bakat apa yang kelak akan menjadi pilihan dirinya sudah dapat distimuli sejak mereka masih bayi atau kanak-kanak itu. Dunia pendidikan mengenal usia emas pada masa kanak-kanak (usia balita). Pada usia ini dianggap strategis dalam peneneman nilai yang positif bagi anak.

Dalam menterafi perilaku menyimpang, maka perilaku baru yang ditawarkan sedapat mungkin memenuhi kepuasan pikirannya yang 
bernilai positif. Pikirannya sedapat mungkin menerima fakta kebenaran perilaku yang baru, sebagai lebih maslahat, lebih sehat dan lebih membahagiakan.

Dengan demikian pendekatan behavioris Islami tidak murni perilaku bentukan tapi potensi dasar (fitrah) yang terlibat dalam proses penentuan perilaku yang akan dipilihnya. Kelemahan pendekatan behavioris menyebabkan munculnya pendekatan baru yang memadukan perilaku luar dan dalam atau pikiran dikenal dengan pendekatan kognitif-perilaku.

\section{Pendekatan Humanistik Islami}

Dalam teori konseling barat, beberapa teknik yang relevan dengan madzhab umanistic itu dikenal antara lain client-center oriented dan logotherapi. Dikatakan relevan karena asumsi-asumsi yang dimiliki oleh pendekatan tersebut sangat memfokuskan perhatiannya terhadap nilai manusia. Gagasan yang muncul dari kalangan umanistic itu merupakan reaksi terhadap cara pandang madzhab sebelumnya yang dinilai kurang menghargai manusia. Tokoh Client center, Rogers misalnya menolak pandangan Freud bahwa perilaku manusia cenderung tidak disadari, irrasional dan destruktif. Sebaliknya Rogers beranggapan bahwa manusia memiliki kemampuan untuk membimbing, mengatur dan mengendalikan dirinya sendiri (Latipun, 2008 : 97).

Manusia menurut Rogers memiliki karakteristik antara lain cenderung melakukan aktualisasi diri, perilakunya didasarkan pada persepsi subjektif terhadap medan fenomenal, bermartabat, berharga, memiliki nilai-nilai yang dijunjung tinggi sebagai hal yang baik bagi dirinya, memiliki potensi dasar yang baik, dapat dipercaya dan konstruktif (Latipun, 2008 : 97).

Mengapa dalam hidupnya manusia kemudian terjebak pada perilaku yang bermasalah, atau dirinya sendiri terkungkung dalam suatu permasalahan yang tiada ujung sehingga menyusahkan dirinya? Analisa Client centered menyebutkan hal itu karena adanya ketidaksesuaian (tidak kongruen) antara pengalaman dengan self, misalnya merasa tidak memperoleh penghargaan secara positif dari orang lain, mengalami kecemasan yang ditunjukkan oleh ketidakkonsistenan mengenai konsep dirinya, defensive, dan berperilaku salah suai (Latipun, 2008: 103). Maksud ketidaksesuaian tersebut bahwa pengalaman hidup yang ia jalani dan rasakan sebagai 
tidak sesuai dengan system self-nya (imajinasi dan konsep diri). Setiap pengalaman yang tidak selaras dengan organism atau struktur self akan diamati sebagai ancaman dan menimbulkan ketegangan psikologis.

Struktur self yang dimiliki seseorang merupakan buah dari interaksi dirinya dengan orang lain atau lingkungan sekitar. Berdasarkan penilaian orang lain tentang dirinya, ia menyetujui apa yang dinilai itu dan membentuk struktur self-nya. Dan masalah pada dirinya terjadi ketika dirinya menolak penilaian itu karena dipandang tidak sesuai.

Pendekatan client centered berasumsi bahwa seseorang dapat mampu keluar dari masalah dirinya dengan cara memberikan keleluasaan pada dirinya untuk menemukan cara-cara menghadapi kenyataan secara lebih sempurna. Klien diharapkan mampu menemukan konsep dirinya yang sesuai dengan medan fenomenalnya dan tidak lagi menolak pengalamannya. Pengalaman disadari sebagai sebuah kenyataan, menjadikan pengalaman sebagai pusat evaluasi, dan akhirnya dapat hidup dengan orang lain secara harmonis, tetap menghargai karakter secara timbale balik.

Pendekatan kedua, logoterapi. Manusia dihargai karena nilai-nilai yang memberikan penghargaan bagi manusia sehingga menjadi lebih terhormat. Nilai-nilai yang memungkinkan seseorang dapat menemukan makna hidup di dalamnya. Nilai tersebut adalah Creative Values (nilainilai kreatif), Eksperiental Values (nilai-nilai penghayatan), dan Attitudinal Values (nilai-nilai bersikap). Creative Values (nilai-nilai kreatif) meliputi kegiatan berkarya seperti bekerja, menciptakan sesuatu, melaksanakan tugas, dan hal-hal lain yang bermanfaat bagi umat manusia. Eksperiental Values (nilai-nilai penghayatan) meliputi keyakinan dan penghayatan akan nilai-nilai kebenaran, kebajikan, keindahan, keimanan, cinta kasih dan sebagainya. Sedangkan Attitudinal Values (nilai-nilai bersikap) meliputi sikap menerima terhadap sesuatu (kejadian atau musibah) yang tidak dapat dielakkan lagi, dengan penuh ketabahan, kesabaran, dan keberanian. Kejadian itu uma berupa sakit yang tidak kunjung sembuh, kematian, dan sebagainya.

Namun demikian pendekatan logoterapi belum tentu menyerupai client-centered apalagi pendekatan tersebut tidak tertutup dengan adanya kelemahan atau kekurangan. Upaya penyadaran manusia tentang nilai yang melekat pada dirinya belum tentu dapat diperoleh hanya mengandalkan kemampuan dirinya. Dalam kondisi seperti ini 
diperlukan orang lain yang memiliki kemampuan lebih, seorang terdidik dan terlatih atau professional. Teknik-teknik yang dikembangkan sangat mungkin menerima teknik-teknik yang ada pada pendekatan lain sepanjang itu relevan umanis kesesuaian dengan upaya menanamkan kesadaran individu terhadap nilai. Jika client centered awalnya mengandalkan non-directive counseling, maka dalam logoterapi memungkinkan dilakukan directive counseling pada kondisi tertentu.

Integrasi Islam dengan pendekatan umanistic ini, mengambil bentuk penyesuaian dan penyelarasan dengan sedikit mengingatkan keterbatasan manusia sebagai makhluk dan bukan sebagai tuhan yang akan memainkan peran segalanya. Selain nilai penghormatan tentang diri manusia harus sadar pula tentang peran tuhan di dalamnya. Humanisme di Barat pernah membuat manusia menjadi sombong seakan segala sesuatu ditentukan oleh dirinya. Islam memperkenalkan pentingnya kearifan dalam melihat sesuatu termasuk kepada dirinya sendiri. Penghormatan kepada kitab suci yang dibawa oleh para nabi, apresiasi terhadap relung ruhaniah, dan transendensi. Bukankah Maslow bapak psikologi umanistic mengakui ada kebutuhan lain yang dinamakan peak experience yang bersifat spiritual.

Ketiadaan konsep tuhan dalam diri, mungkin saja pendekatan umanistic berhasil membangun kesadaran baru kepada manusia, namun bahayanya dapat melahirkan manusia yang over-confidence. Ini cikal bakal kesombongan yang sangat tidak diharapkan oleh Islam. Untuk itu dalam pendekatan umanistic umanistic-Islami ditekankan membangun kesadaran tanpa menghilangkan spirit Islam yang tidak memisahkan peran manusia dengan tuhan. Keimanan terhadap wahyu ilahi serta pengakuan akan keteladanan Muhamad Saw. Sebagai Nabi turut mewarnai pemikiran humanistic dalam Islam. Humanistik dalam Islam menjadi lebih holistic baik sebagai pikiran maupun tindakan.

\section{Pendekatan Spiritual Islami}

Kata spiritual memiliki akar kata spirit yang berarti roh. Kata ini berasal dari bahasa Latin, spiritus, yang berarti napas. Roh bisa diartikan sebagai energi kehidupan, yang membuat seseorang dapat hidup, bernapas dan bergerak. Spiritual berarti pula segala sesuatu di luar tubuh fisik, termasuk pikiran, perasaan, dan karakter. Kecerdasan spiritual berarti kemampuan seseorang untuk dapat mengenal dan memahami diri sepenuhnya sebagai makhluk spiritual maupun sebagai 
bagian dari alam semesta. Dengan memiliki kecerdasan spiritual berarti seseorang memahami sepenuhnya makna dan hakikat kehidupan yang ia jalani dan ke manakah ia akan pergi. Jika merujuk pada agama, pada awal penciptaan manusia, Tuhan meniupkan roh/napas kehidupan kepada manusia. Roh adalah sesuatu yang membuat manusia hidup.

Spiritualitas merupakan kebutuhan tertinggi manusia. Ahli jiwa termashur Abraham Maslow, dalam Makalahnya Hierarchy of Needs menggunakan istilah aktualisasi diri (self-actualization) sebagai kebutuhan dan pencapaian tertinggi seorang manusia. Maslow menemukan bahwa, tanpa memandang suku atau asal-usul seseorang, setiap manusia mengalami tahap-tahap peningkatan kebutuhan atau pencapaian dalam kehidupannya. Kebutuhan tersebut meliputi: Kebutuhan fisiologis (Physiological), meliputi kebutuhan akan pangan, pakaian, tempat tinggal maupun kebutuhan biologis. Kebutuhan keamanan dan keselamatan (Safety), meliputi kebutuhan akan keamanan kerja, kemerdekaan dari rasa takut ataupun tekanan, keamanan dari kejadian atau lingkungan yang mengancam, Kebutuhan rasa memiliki, sosial dan kasih sayang (Social), meliputi kebutuhan akan persahabatan, berkeluarga, berkelompok, interaksi dan kasih sayang, Kebutuhan akan penghargaan (Esteem), meliputi kebutuhan akan harga diri, status, prestise, respek dan penghargaan dari pihak lain, Kebutuhan aktualisasi diri (self-actualization), meliputi kebutuhan untuk memenuhi keberadaan diri (self fulfillment) melalui memaksimumkan penggunaan kemampuan dan potensi diri.

Kebutuhan manusia berdasarkan pada urutan prioritas, dimulai dari kebutuhan dasar, yang banyak berkaitan dengan unsur biologis, dilanjutkan dengan kebutuhan yang lebih tinggi, yang banyak berkaitan dengan unsur kejiwaan, dan yang paling tinggi yaitu aktualisasi diri tersebutlah yang dimaksud dengan kebutuhan spiritual. Jika dan hanya jika seluruh kebutuhan fisiologis dan kejiwaan seseorang tercapai, dia dapat mencapai tahap perkembangan tertinggi yaitu, aktualisasi diri. Maslow mendefinisikan aktualisasi diri sebagai sebuah tahapan spiritualitas seseorang, di mana seseorang berlimpah dengan kreativitas, intuisi, keceriaan, sukacita, kasih, kedamaian, toleransi, kerendah-hatian, serta memiliki tujuan hidup yang jelas, dan misi untuk membantu orang lain mencapai tahap kecerdasan spiritual ini.

Menurut Maslow, pengalaman spiritual adalah peak experience, plateau - the farthest reaches of human nature. Pengalaman spiritual 
adalah puncak tertinggi yang dapat dicapai oleh manusia serta merupakan peneguhan dari keberadaannya sebagai makhluk spiritual. Pengalaman spiritual merupakan kebutuhan tertinggi manusia. Bahkan Maslow menyatakan bahwa pengalaman spiritual telah melewati hierarki kebutuhan manusia, going beyond humanness, identity, selfactualization, and the like."

Ibadah dengan motivasi karena ketakutan (fear motivation) menunjukkan kecerdasan spiritual yang paling bawah, dilanjutkan dengan motivasi karena hadiah (reward motivation) sebagai kecerdasan spiritual yang lebih baik. Tingkatan ketiga adalah motivasi karena memahami bahwa kitalah yang membutuhkan untuk menjalankan ibadah agama kita (internal motivation), dan tingkatan kecerdasan spiritual tertinggi adalah ketika kita menjalankan ibadah agama karena kita mengetahui keberadaan diri kita sebagai makhluk spiritual dan kebutuhan kita untuk menyatu dengan Sang Pencipta berdasarkan kasih (love motivation).

Paling tidak ada lima hal yang diajarkan oleh agama untuk membantu seseorang meningkatkan kecerdasan spiritualnya, yaitu: Pertama, iman atau keyakinan. Manusia harus menyadari dan meyakini sebagai ciptaan Tuhan dan memiliki potensi yang luar biasa untuk menjadi dan memiliki apa pun yang diharapkan. Potensi dan peluang yang tidak terbatas inilah yang harus dieksplorasi dan dikembangkan dalam rangka mewujudkan impian-impian serta misi hidup manusia bagi sesama dan dunia pada umumnya.

Kedua, ketenangan dan keheningan, yaitu suatu upaya ritual untuk menurunkan frekuensi gelombang otak manusia sehingga mencapai alpha (relaks) sampai tahap meditatif pada keheningan yang dalam. Semua agama mengajarkan cara untuk bersembahyang dan meditasi. Dalam Islam adalah Shalat, yang sebenarnya merupakan tahap di mana otak membutuhkan istirahat untuk mencapai kejernihan dan ketenangan. Sembahyang lima waktu merupakan kebutuhan manusia untuk memasuki frekuensi gelombang otak yang rendah, untuk mencapai kecerdasan yang lebih tinggi, kreativitas, intuisi dan tuntunan Ilahi. Pada frekuensi rendah juga terjadi peremajaan sel-sel tubuh (rejuvenation) sehingga kita menjadi lebih sehat dan awet muda.

Ketiga, pembersihan diri, berupa detoksifikasi yaitu pembuangan racun-racun. Misal melalui puasa karena puasa merupakan sebuah proses bagi seseorang untuk membersihkan tubuh dari segala racun- 
racun dan sisa pembuangan metabolisme tubuh, serta memberi waktu bagi tubuh untuk beristirahat. Jadi terlihat jelas bahwa berpuasa adalah kebutuhan mutlak seseorang untuk memelihara kesehatannya, selain bahwa puasa membantu pelakunya untuk mencapai ketenangan (frekuensi gelombang otak yang rendah) sehingga ia dapat mencapai kesadaran tertinggi (superconsciousness).

Keempat, beramal dan mengucap syukur (Charity and Gratitude). Beramal bukan untuk kebutuhan orang lain semata. Justru seseorang butuh untuk melakukan amal karena terbukti dalam penelitian bahwa rasa iba dan kasih sayang menstimulasi pembentukan hormon yang meningkatkan daya tahan tubuh dan kesehatan kita. Beramal dan mengucap syukur adalah sebuah pernapasan rohani, yang jika tidak lakukan maka manusia akan mati secara spiritual dalam arti semakin tidak dapat mencapai tahapan aktualisasi diri atau pemenuhan diri yang sempurna.

Kelima, penyerahan diri secara total. Ini adalah tahapan tertinggi dalam perjalanan spiritualitas seseorang, yaitu ketika dia sudah tidak punya rasa kuatir akan apa yang akan terjadi. Dia memiliki rasa pasrah secara total kepada Tuhan, karena sebagai makhluk spiritual, dia telah mencapai penyatuan dengan sang Pencipta. Mengapa orang naik Haji diberangkatkan dengan doa seperti orang mendoakan yang meninggal. Selain mungkin bahwa ada risiko meninggal dalam menjalankan ibadah haji, hal tersebut bermakna bahwa ketika seseorang berangkat haji, berarti dia sudah menyerahkan hidupnya sepenuhnya kepada Sang Pencipta.

Integrasi Islam dalam spiritualitas tampak jelas, terlebih ilustrasi di atas kendati sebagian pikiran Maslow tentang spiritual sebagai peak experience yang diungkap, tetapi cukup menggambarkan eksistensi spiritual pada manusia, hanya saja upaya-upaya ke arah pencapaian spiritual lebih tampak jelas dan lengkap dalam Islam, sebab ajaran Islam mengokohkan tentang arti nilai, bukan sekedar kebutuhan manusia sebagai makhluk sosial dan psikologis tetapi juga wujud fitrah dan pengabdian yang seharusnya melekat pada tiap pribadi manusia.

\section{Penutup}

Pengembangan teori bimbingan konseling Islam perlu mempertimbangkan integrasi dengan Barat. Perkembangan teori di satu sisi teori Islam dengan geneologi yang jelas dan berakar pada praktik 
dakwah Rasul, yang kemudian berlanjut dikalangan sahabat, dan kini muncul dalam sosoknya yang orsinil paling tidak dengan berbasis pada pikiran-pikiran filosof muslim. Di sisi lain dunia barat juga mulai mengakui adanya peran agama dalam konseling. Mereka beranggapan bahwa teori konseling akan menjadi lebih optimal jika diintegrasikan dengan agama.

Beberapa pendekatan konseling barat sudah memiliki istilahistilah keilmuan yang jelas sesuai dengan ciri yang digunakannya, dan mereka akan menganggap itu sebagai hasil temuan barat. Sejalan dengan itu Islam juga memandang ada kesejalanan penggunaan pendekatan itu. Tampaknya langkah yang bijak ketika pengembangan teori bimbingan konseling Islam dilakukan dengan integrasi keduanya.[]

\section{DAFTAR PUSTAKA}

Amril, M. 2002. Etika Islam, Tela'ah Pemikiran Filsafat Moral Raghib AlIsfahan. Yogyakarta: Pustaka Pelajar.

Corey, Gerald. 2005. Theory and Practice of Counseling and Psychotherapy. Seven Edition. USA: Brooks/Cole Thompson.

Hamdan, Aisha. 2008. Cognitive Restructuring: An Islamic Perspective. United Arab Emirates: University of Sharja.

Latipun. 2008. Psikologi Konseling, Edisi Ketiga. Malang: Universitas Muhammadiyah.djusment, Third Edition. Tokyo: McGraw-Hill Koga Kusha Ltd.

McLeod, John. 2008. Pengentar Konseling Teori dan Kasus. Jakarta: Kencana Prenada Media Group.

Rakhmat, Jalaluddin. 1989. Psikologi Komunikasi. Bandung: Remaja Rosda Karya.

Spiegler, Michael D.\& Guevremont, David G. 2003. Contemporary Behavior Therapy. Fourth Edition. USA: Thompson,

Suwignjo, Johan. 2008. Emosi, Pikiran dan Suara Hati. Bandung: Alfabeta.

Surya, Muhammad. 2009. Psikologi Konseling. Bandung: Pustaka Setia 